MORAL NIMBY-ISM?

\title{
UNDERSTANDING SOCIETAL SUPPORT FOR MONETARY COMPENSATION TO PLASMA DONORS IN CANADA
}

\author{
NICOLA LACETERA* AND MARIO MACIS** \\ I
}

INTRODUCTION

The legal status and regulation of economic transactions does not depend only on considerations about their economic efficiency, but also on the societal support for a particular exchange to occur through a market (if at all). Widely held concerns that the individuals engaging in certain transactions may be exploited or unduly influenced; that the terms of trade may not be fair; or that some transactions violate human dignity, the sanctity of life, or traditional institutions; may lead a society to prohibit certain trades. ${ }^{1}$ These principles may represent sacred values that take priority over material considerations and contribute to defining common identities or a collective conscience that allows even complex societies to be tied together. ${ }^{2}$ Alvin Roth defines as "repugnant" those transactions that third parties wish to prohibit even if the underlying

Copyright $(92018$ by Nicola Lacetera and Mario Macis.

This article is also available online at http://lcp.law.duke.edu/.

Associate Professor of Management, University of Toronto and University of Toronto Mississauga, Chief Scientist at Behavioural Economics in Action @ Rotman, Research Associate at the National Bureau of Economic Research, and a Fellow at CESifo, the U of T Centre for Ethics, the Canadian Centre for Health Economics, and the Bureau of Research on Innovation, Knowledge and Complexity.

** Associate Professor of Economics, Johns Hopkins University Carey Business School; Associate Faculty, Johns Hopkins School of Medicine Armstrong Institute; Faculty research fellow, National Bureau of Economic Research (NBER), Institute for the Study of Labor (IZA, and Center for NorthSouth Economic Research (CRENoS)). This research was funded in part by the Johns Hopkins University Catalyst Award.

1. See Debra Satz, Why Some Things Should Not Be for Sale: The Moral Limits of MARKETS 94-98 (Samuel Freeman ed., 2010) (listing four primary indicators of noxious markets: extremely harmful outcomes for participants or third parties, extremely harmful outcomes for society, highly asymmetric knowledge on the part of participants, and extreme vulnerabilities of transacting parties).

2. See Emile Durkheim, The Division of Labor IN Society 38-39 (Anthony Giddens ed., W.D. Halls trans., 1984) (arguing that society's shared moral values create a "collective consciousness," and acts are considered criminal when they offend this shared consciousness). 
exchanges may be beneficial for the parties directly involved. ${ }^{3}$

Examples of transactions that raise or have raised moral concerns often leading to their prohibition include prostitution, same-sex marriage, indentured servitude, and markets for human organs for transplantation. ${ }^{4}$ As one considers this (incomplete) list of examples, one observation that emerges is that the legal treatment of several of these transactions has changed over time in many countries. For instance, same-sex marriage, which until recently was nearly universally prohibited because it was regarded as in conflict with religious and traditional values, is now legal in several countries. ${ }^{5}$ Additionally, countries that otherwise share many similarities in terms of social structure, level of economic development, and historical and cultural roots treat certain transactions differently. For example, prostitution is legal in Germany but illegal in France, and commercial surrogacy is legal in several jurisdictions in the United States ${ }^{6}$ but illegal in Canada. ${ }^{7}$

These legislative choices raise several questions as to whether the different legal treatments of certain transactions actually reflect different levels of societal support for those activities across countries, and if so, why. Moreover, seeming inconsistencies introduce additional challenges to our understanding of what explains support for, or opposition to, morally contentious transactions. This article will focus on one such apparent inconsistency: the case of plasma donations in Canada and the United States. The United States allows payments for plasma donors and the establishment of for-profit plasma centers. In most provinces of Canada, in contrast, payments to plasma donors are illegal. Canadian policy makers justify the ban on compensation on the basis of moral considerations and on concerns regarding the safety of plasma collected from paid donors. However, Canada relies on imported plasma from American paid donors to meet its need for plasma-derived therapies. For example, approximately $83 \%$ of immunoglobulin, which is used in Canada (and elsewhere) to treat several immune, blood and neurological disorders, is made from plasma imported from American for-profit plasma centers. ${ }^{8}$

Evidence about the degree of social support (or disapproval) for morally controversial activities is scant. Even less evidence is available regarding whether the social support is general or country specific; for example, whether the moral

3. See Alvin E. Roth, Repugnance as a Constraint on Markets, 21 J. ECON. PERSP. 37, 38 (2007).

4. Id. at 39 .

5. Gay Marriage Around the World, PEw RES. CTR. (Aug. 8, 2017), http://www.pewforum.org/ 2017/08/08/gay-marriage-around-the-world-2013/ [https://perma.cc/2VRD-9D3S].

6. See Kimberly D. Krawiec, Altruism and Intermediation in the Market for Babies, 66 WASH. \& LEE L. REV. 203, 225 (2009) ("Some states, either through statute or court decisions, take approaches relatively friendly to commercial surrogacy arrangements, for example, by analyzing the parties' intent at the time of the contract.").

7. Assisted Human Reproduction Act, S.C. 2004, c. 2 (Can.).

8. Our Commitment to Increasing Plasma Sufficiency in Canada, CAN. Blood Serv., https://blood.ca/en/blood/plasma-sufficiency [https://perma.cc/CZ7C-YZZX] (last visited Mar. 1, 2018). 
opposition that a society may have toward a certain trade refers only to allowing that trade in that same country, or everywhere. In particular, individuals may display some form of "moral NIMBY-ism"; that is, they may wish to reap the benefits from a contested transaction (compensated plasma donation) while outsourcing the moral costs of it. Thus, with specific reference to the case of plasma donations in Canada, this article asks the following questions:

- How prevalent is the opposition to compensating plasma donors in Canada?

- What are the main reasons for and against payments? What is the relative importance of moral concerns, of concerns regarding safety, and of considerations about the importance of guaranteeing a sufficient supply to cover medical needs?

- Are Canadians opposed to paying all plasma donors, or just Canadian plasma donors?

- Do the majority of Canadians exhibit "consequentialist" preferences (that is, considerations about the practical impacts of allowing payments are important to their attitudes toward payments), or "deontological" preferences (meaning their opposition to compensating plasma donors reflects a "sacred" value that cannot be sacrificed)?

We conducted a randomized survey experiment with a representative sample of 826 Canadian residents. In the survey, respondents were randomly assigned to express their opinion in favor or against compensating plasma donors in one of three countries: Canada, the United States, or Australia. Similar to Canada, compensation to plasma donors is not allowed in Australia, and Australia also relies on imported plasma to satisfy its domestic needs. ${ }^{9}$ Next, according to whether the subjects were in favor of or against paying plasma donors, we asked how much the respondents agreed with a set of possible motivations for their position. The sentences that expressed these motivations stressed the morality of allowing or not allowing payments, the risk of attracting donors with transmittable diseases if payments were legal, and the importance (or lack thereof) of guaranteeing a sufficient domestic supply. By asking a representative sample from one country about support for payments in their own country or elsewhere, we can determine whether attitudes are general or specific to a person's country of residence. The additional questions about the individuals' motives behind their stances further help to identify not only the differential relevance of these motives, but also the weight assigned to them when referring to one's own country as opposed to other countries.

Part II provides details on plasma uses and collection in Canada, Australia, and the United States. Part III describes our experimental design. Part IV

9. Robert Slonim, Carmen Wang \& Ellen Garbarino, The Market for Blood, 28 J. ECON. PERSP. 177, 185 (2014). 
presents our results, and Part V draws conclusions.

II

\section{INSTITUTIONAL DETAILS}

\section{A. Plasma Uses And Plasma Donation}

Plasma is the liquid part of blood that remains after removing red blood cells, white blood cells, platelets, and other cellular components. ${ }^{10}$ It consists of water, salts, enzymes, antibodies and other proteins (such as albumin, fibrinogen, and globulins), and it performs several functions, including clotting blood and fighting infections.

Plasma is used for direct transfusion. It is also used in the production of therapies to treat people with chronic diseases and disorders such as primary immunodeficiency, hemophilia and genetic lung disease, and in the treatment of trauma, burns and shock. Source plasma is plasma that is collected from healthy, voluntary donors through a process called plasmapheresis and is used for further manufacturing into final therapies (a process called fractionation) ${ }^{11}$ Recovered plasma is collected through whole blood donation in which plasma is separated from its cellular components. Recovered plasma may also be used for fractionation. Producing all of these therapies requires a large number of plasma donations. For example, the annual treatment of one single patient with hemophilia requires 1,200 plasma donations. ${ }^{12}$

During a source plasma donation, blood is drawn from one arm and channeled through an automated machine that collects the plasma and returns the remaining blood components (white blood cells, red blood cells, and platelets) to the donor. It typically takes between one and three hours to donate source plasma.

Stringent regulations are in place for the screening and testing of plasma donors. Moreover, the manufacturing process for plasma products includes multiple, mandatory steps that remove or inactivate any contaminants, including viruses that could be present. These viral inactivation steps have proven to be effective at eliminating new pathogens such as West Nile Virus, which has been transmitted by blood transfusion but never by use of plasma products. More generally, over the last few decades, plasma product manufacturing technology has evolved, and many of the identified risks from the past have been mitigated or eliminated. ${ }^{13}$

10. What is Plasma?, DONATING PlASMA, http://www.donatingplasma.org/donation/what-isplasma [https://perma.cc/UGR9-SER6] (last visited Feb. 18, 2018).

11. Slonim et al., supra note 9 , at 183.

12. GRIFOLS, PlASMA: A SOURCE OF LIFE, https://www.grifolsplasma.com/en/web/plasma/aboutplasma-donation/plasma-a-source-of-life [https://perma.cc/S6EL-8ZGP] (last visited Feb. 18, 2018).

13. Plasma Donation in Canada, Gov'T CAN. (Jan. 5, 2018), https://www.canada.ca/en/healthcanada/services/drugs-health-products/biologics-radiopharmaceuticals-genetic-therapies/activities/factsheets/plasma-donation-canada.html [https://perma.cc/29SX-J4LH]. 


\section{B. Plasma Collection in Canada, Australia, and the United States}

Compensation for plasma donors - specifically, for the supply of plasma to be used for fractionation-and the establishment of for-profit plasma centers are legal activities in several countries, such as the United States, Czech Republic, and Austria. Many other countries prohibit payments. ${ }^{14}$ A common feature of most countries that ban compensation is that they run a deficit of plasma for domestic uses; therefore, they rely on imports, most often of plasma collected in countries where compensation is legal because, typically, these countries have a surplus of available plasma. ${ }^{15}$ The different legal status of payments to donors around the world and the international plasma procurement and allocation patterns are somewhat exemplary of the challenges in defining repugnant trades and in determining the reasons for bans to compensation.

In Canada, most provinces prohibit compensation to plasma donors. Ontario and Alberta passed legislation that prohibits compensation for plasma in 2014 and 2017, respectively. ${ }^{16}$ In Quebec, payments to plasma donors have been illegal since 1994, ${ }^{17}$ and currently, British Columbia and Nova Scotia are considering similar legislation. ${ }^{18}$ Private plasma centers that pay donors are active in Saskatchewan though. ${ }^{19}$ However, there is a debate about banning compensation for plasma donors at the federal level. ${ }^{20}$

Canadian Blood Services and Héma-Québec are the only organizations that collect plasma (and blood) for transfusion, and they do so exclusively from unpaid donors. ${ }^{21}$ Plasma collected from volunteers in Canada is sufficient for

14. Slonim et al., supra note 9 , at 185 .

15. See Blood Safety and Availability - Fact Sheet, WorLd HeAlth ORG. (June 2017), http://www.who.int/mediacentre/factsheets/fs279/en/ [https://perma.cc/2SB5-J3PY]. See generally Plasma Fractionation ReView COMmittee, COMmONWEAlth of Australia, Review of AUSTRALIA's PLASMA FRACTIONATION ARRANGEMENTS 69-83 (2006),

https://www.health.gov.au/internet/main/publishing.nsf/Content/B3B4E1D741764DD2CA257BF000193 A6F/\$File/plasma_FINAL\%20as\%20at\%2030\%20November\%202006.pdf [https://perma.cc/4Z7H$9 \mathrm{VWW}$ (describing several countries' processes for acquiring the necessary amount of plasma).

16. Voluntary Blood Donations Act, S.A. 2017, V-5 (Can.); Voluntary Blood Donations Act, S.O. 2014, c. 14 (Can.).

17. Civil Code of Québec, CQLR c CCQ-1991 art. 25 (Can.).

18. See Debates and Proceedings on Bill No. 37, Voluntary Blood Donations Act Before the House of Assembly of Nova Scotia, 1064-1080 (2017) (Can.) (debating the merits of the proposed bill, the Voluntary Blood Donations Act); Kelly Grant, Blood Agency Seeking \$855-Million in Funding to Boost Plasma Supply, Document Reveals, GLOBE \& MAIL (Aug. 14, 2017), https://beta.theglobeandmail.com/ news/national/blood-agency-seeking-855-million-in-funding-to-boost-plasma-supply-documentreveals/article35980339/?ref=http://www.theglobeandmail.com\& [https://perma.cc/MJ8H-F4AS].

19. See Canadian Plasma Clinic That Pays Donors $\$ 25$ per Visit Opens in Saskatoon, CBC News (Feb. 19, 2016), http://www.cbc.ca/news/canada/saskatoon/plasma-clinic-opens-saskatoon-1.3453062 [https://perma.cc/E322-PAMU].

20. The Canadian Press, NDP: Plasma Clinics That Pay Donors Should Be Banned by Federal Government, HUFFINGTON POST (Jan. 15, 2016), http://www.huffingtonpost.ca/2016/01/15/ndp-wantsfederal-ban-on-plasma-clinics-that-pay-donors-but-saskatchewan-oks-it_n_8992022.html [https://perma.cc/LJ7R-6T3H].

21. See CANAdian Blood Services, HÉma-QuÉBEC, https://blood.ca/en/news-tags/hema- 
transfusions across the country. However, the domestic supply of plasma for the production of therapies and pharmaceutical products is not sufficient to meet the domestic demand. Imported plasma products make up for the difference. ${ }^{22}$

In Australia, Australian Red Cross Blood Service (ARCBS) is the only organization that collects plasma (and blood) for transfusion and fractionation, and they do so exclusively from unpaid donors because payments to donors are not allowed. The biopharmaceutical company CSL Limited fractionates plasma from ARCBS donations and supplies a range of immunoglobulin, hyper-immune products, clotting factors and albumin, for domestic use. Similar to Canada, plasma collected from Australian volunteers is sufficient for blood transfusions in the country. However, the domestic supply of plasma for the production of therapies and pharmaceutical products is not sufficient to meet the domestic demand, so Australia must import plasma products to fulfill the medical needs of its patient population. ${ }^{23}$

In contrast, plasma donors in the United States receive compensation. Individuals can donate a maximum of two times within a seven-day period, ${ }^{24}$ receiving about $\$ 30$ per donation. ${ }^{25}$ In the United States, the supply of plasma is sufficient to meet the domestic demand:26 moreover, the United States exports plasma to other countries, including Canada and Australia. ${ }^{27}$ For example, approximately $83 \%$ of immunoglobulin used in Canada is made from American paid plasma donors. ${ }^{28}$ Similarly, Australia imports $43 \%$ of its immunoglobulin from outside of Australia. ${ }^{29}$

III

EXPERIMENTAL DESIGN

We conducted a survey experiment with a sample of 826 Canadian

quebec [https://perma.cc/5GSN-WF7A] (last visited Feb. 18, 2018).

22. Backgrounder Paper-Plasma Donations in Canada, Gov'T CAN. (June 27, 2013), https://www.canada.ca/en/health-canada/services/drugs-health-products/public-involvementconsultations/biologics-radiopharmaceuticals-genetic-therapies/backgrounder-paper-plasma-donationscanada.html [https://perma.cc/45BJ-J3BB].

23. See NAT'L Blood Authority Austl., ANNuAl Report 2015-16 39 (2016) (explaining the National Blood Authority's contracts with plasma suppliers to complement domestic supply when domestic plasma production cannot meet demand).

24. 21 C.F.R. $\S 640.65$ (2017).

25. See, e.g., Alexa Valiente, Mark Abdelmalek \& Lauren Pearle, Why Thousands of Low-Income Americans "Donate" Their Blood Plasma to For-Profit Centers, ABC News (Jan. 13, 2017), $\mathrm{http} / / /$ abcnews.go.com/US/thousands-low-income-americans-donate-blood-plasma-profit/story? $\mathrm{id}=44710257$ [https://perma.cc/J9UZ-7ASF].

26. Slonim, et al., supra note 9, at 185.

27. See Gilbert M. Gaul, The Blood Brokers-America: The OPEC of the Global Plasma Industry, PHILA. INQUIRER (Sep. 28, 1989), http://www.bloodbook.com/part-5.html [https://perma.cc/ 9AMG-L83M] ("More than half the estimated 12 million liters of plasma used in medicines worldwide comes from the United States.").

28. CANADIAN BLOOD SERVICES, supra note 8.

29. NAT'L BLOOD AUTHORITY AUSTL., supra note 23, at 33. 
respondents recruited by ResearchNow, a market research data company. The recruitment protocol was such that the sample would be representative of the Canadian population for such features as gender, age, and geographical location.

Figure 1 outlines the flow of the survey. All participants first read a text of about 320 words that included general information about plasma and plasma donation: what plasma is, what its medical uses are, the different ways of collecting plasma from donors, some basic features of the process of plasma fractionation and the manufacturing of plasma products, and some information on the quantity of plasma needed to address certain diseases.

The survey then introduced a random-experimental component with a 2-by2 design. With ex-ante $50 \%$ probability, we assigned respondents to one of two texts. The first text provided a description of the plasma procurement and allocation system in Canada - we refer to this group as the "Canada text" group. The text explained that the majority of Canadian provinces, including the largest ones, prohibit compensation to donors as well as the establishment of for-profit plasma centers. It also included a summary of the different positions in the debate about legalizing compensation. Proponents of compensating plasma donors argue that payments would increase supply, and that there have been no instances of contaminated plasma from paid donors in the past twenty years. Among the arguments against payments were the concerns that compensation may hamper the voluntary system, attract donors with communicable diseases, and violate human dignity because certain transactions should be kept out of the market. Finally, the text noted that about $83 \%$ of plasma for fractionation used in Canada is imported from the United States, where payments to plasma donors are legal.

The remaining respondents read a similar text with information about plasma procurement and allocation in Australia, another country that does not allow payments to donors (we refer to this group as the "Australia text" group). The information provided was specific to the Australian case, but the structure of the text, including information about imports from countries that allow payments (for example, the United States), was the same as the text about Canada.

We then further divided the participants in each of the two groups into two subgroups, again with ex-ante $50 \%$ probability for each respondent. Within the "Canada text" group, we asked one subgroup to express their opinion about whether payments to plasma donors should be allowed in Canada (we refer to this subgroup as the "Canada text \& Canada vote" group). We asked the other subgroup whether payments to plasma donors should be allowed in the United States - the "Canada text \& US vote" group. Similarly, for the "Australia text" group, we asked one subgroup to express their opinion about whether payments to plasma donors should be allowed in Australia (the "Australia text \& Australia vote" group), and we asked the other subgroup whether payments to plasma donors should be allowed in the United States ("Australia text \& US vote" group). The respondents could check one of two options: "I think payments to 
plasma donors should be allowed in Canada/Australia/the United States," or "I think payments to plasma donors should not be allowed in Canada/Australia/the United States."

Because all respondents were Canadian residents, this design allowed us to assess both the support for compensation to plasma donors in their own country and the support for payments in other countries. We chose Australia as one of these other countries because, in addition to having cultural similarities and a level of economic development comparable to Canada's, compensation to plasma donors is illegal in Australia, and it imports plasma for fractionation just like Canada. We also included the United States because compensation is legal in the United States and the country runs a vast supply surplus that allows for exports of plasma. Canada relies on this imported plasma. to produce a range of therapies. We could therefore determine whether any support or opposition to compensation was general or specific to the country of residence of the population of interest (Canadians), and whether the current legal framework in a country correlated with the level of agreement or aversion toward compensation.

After the participants answered about their support for compensating plasma donors, the survey directed them to different sets of questions, according to whether they expressed opposition or favor, and according to the country on which they expressed their view. These questions contained statements that reported a set of reasons for being in favor of or against payments. For each of the listed reasons, we asked the respondents to give a rating from 0 to 100 to indicate how important that reason was in motivating their position.

For the "Canada text \& Canada vote" and the "Australia text \& Australia vote" groups, we proposed the following three reasons to those who opposed payments to plasma donors:

- "It is immoral to provide monetary payments to plasma donors in Canada/Australia - donations should be unpaid"

- "Monetary payments may attract donors who carry transmittable diseases"

- "Increasing domestic supply of plasma is not a priority, Canada/Australia can rely on imports"

For those who did not support payments in the United States (respondents in the "Canada text \& US vote" or "Australia text \& US vote" groups), we replaced the third statement above, which is not applicable to the United States because the United States does not rely on imports, with the following:

- "The US produces more plasma than their domestic needs, so paying plasma donors is unnecessary"

For the respondents in the "Canada text \& Canada vote" and the "Australia text \& Australia vote" groups who expressed favor towards payments to plasma donors, we presented the following reasons, again asking the respondents to rate them from 0 to 100 depending on how important each statement was in 
motivating them to be in favor of payments:

- "It is morally appropriate to provide monetary payments to plasma donors in Canada/Australia - they incur costs in terms of time spent donating and physical discomfort to supply a valuable resource"

- "Monetary payments to plasma donors would increase the availability of domestic plasma and reduce Canada's/Australia's dependence on other countries"

- "Plasma donors receive monetary payments in some other countries, such as the United States, therefore they should be paid also in Canada/Australia"

Finally, we provided a list of five reasons to participants in the "Canada text \& US vote" and "Australia text \& US vote" groups who favored compensating plasma donors:

- "It is morally appropriate to provide monetary payments to plasma donors in the United States - they incur costs in terms of time spent donating and physical discomfort to supply a valuable resource"

- "Monetary payments to plasma donors increase the availability of domestic plasma and ensure that the US does not depend on other countries"

- "Some countries, such as Canada/Australia, rely on imported plasma from paid donors in the US"

- "Plasma donors receive monetary payments in some other countries, therefore they should be paid also in the United States"

- "It is currently legal to pay plasma donors in the US, so things should stay as they are"

We chose these motives to encompass some of the main arguments that recur frequently in the debate about the legalization of compensation in Canada and elsewhere: moral considerations, concerns about the safety of plasma donated by paid donors, and the effects of compensation on domestic supply. Because payments are already legal in the United States, we modified the statements accordingly, and also added some statements that were specific to the U.S. case.

We then proposed an additional question only to the respondents who had expressed opposition to payments in the form of a hypothetical scenario. Participants expressed their favor or opposition to the following statement: "If there was a shortage of plasma (i.e., the domestic supply plus the imports were not sufficient to satisfy [Canada's/Australia's/the US'] need for plasma), then I would consider supporting the introduction of monetary payments to plasma donors in Canada/Australia/the US." The reason for having this additional question was to collect more evidence on the underlying motives for opposing payments; a disagreement with the hypothetical statement above would indicate a strong form of opposition, one that reflects deontological preferences and thus is not amenable, for example, to making trade-offs between different values or objectives. Conversely, an agreement with the statements would indicate that 
although the respondent currently opposes payments to plasma donors, her preferences are more consequentialist, which implies that she is willing to make trade-offs between moral arguments and supply considerations.

The last part of the survey, common to all respondents, included a series of socio-demographic questions. We asked participants to report their age, gender, ethnicity, religious beliefs, household income, education level, marital status, job market status, geographical area of residence within Canada, whether they had children, their views about social and economic issues, and whether they had volunteered or donated to charity in the previous two years.

Figure 1: Experimental design flow.

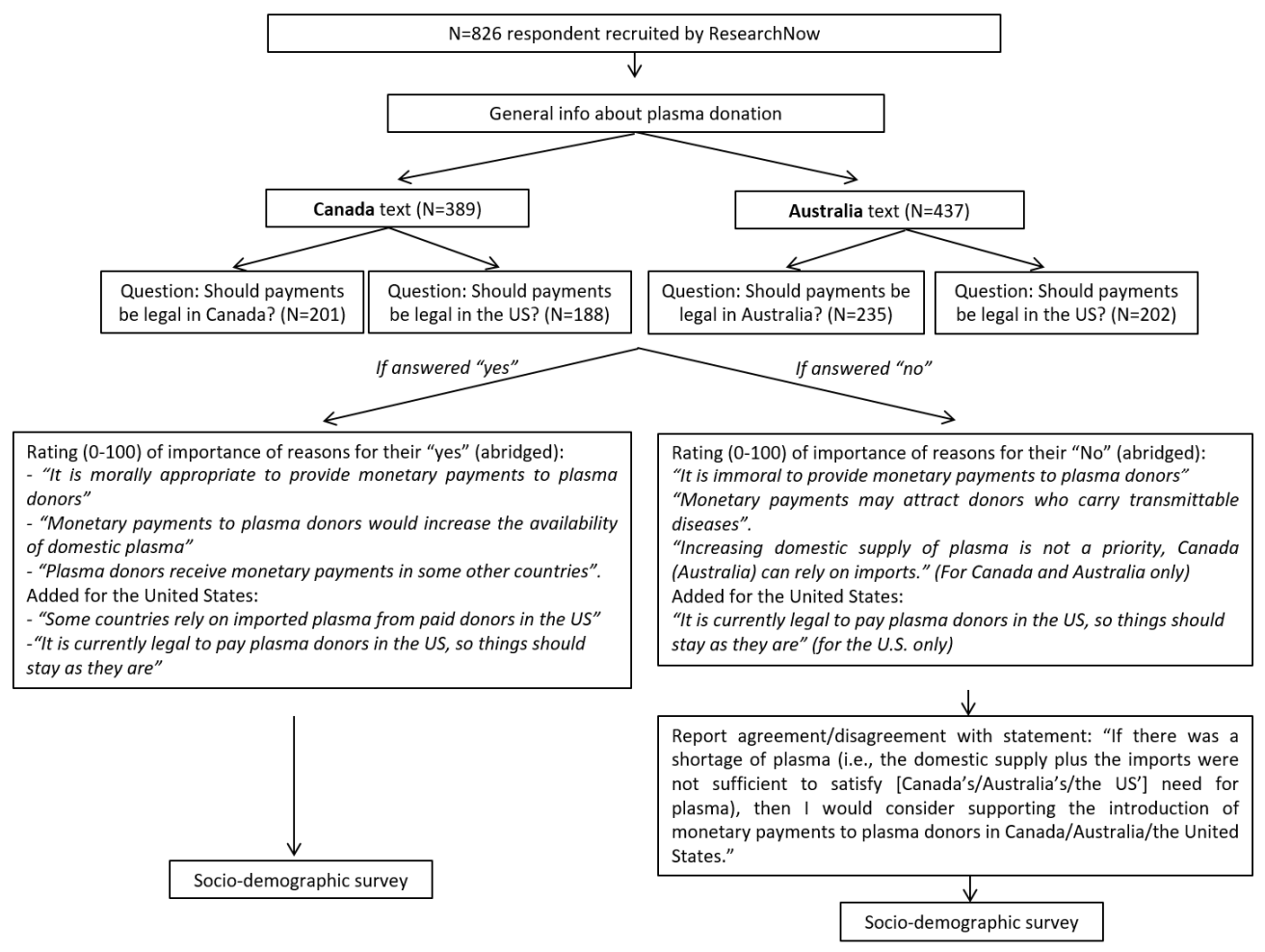

IV

DATA AND RESULTS

\section{A. Sample and Balance Checks}

Table 1 reports some summary features of the 826 respondents. Consistent with our design, the sample is reasonably representative of the distributions by gender, age, ethnicity, geographic region, religious attitude, education, work 
status, family status, income, and political orientation of the Canadian population. To check whether the sample was well-balanced across the four experimental conditions, we estimated a multinomial logit regression of the four treatment conditions on indicators for various socio-demographic features; we found that the participants' characteristics are unrelated to the treatment to which the participants were assigned $(p>$ chi2 $=0.957)$.

Table 1: Descriptive statistics.

This table reports the distribution of the socio-demographic characteristics of the 826 survey respondents.

\begin{tabular}{lcll} 
N. of respondents & 826 & & \\
\hline Women & $52.2 \%$ & College degree & $50.4 \%$ \\
& & & \\
Age $18-34$ & $27.8 \%$ & Employed & $53.9 \%$ \\
Age $35-54$ & $38.5 \%$ & Retired & $21.2 \%$ \\
Age $55+$ & $33.7 \%$ & & \\
& & & $53.1 \%$ \\
Caucasian/White & $74.2 \%$ & Married & $53.1 \%$ \\
East Asian & $9.3 \%$ & With children & $69.2 \%$ \\
Other & $16.5 \%$ & Income $>$ \$50K & $43.5 \%$ \\
& & & $18.1 \%$ \\
Atlantic & $7.4 \%$ & Liberal on social issues & $33.7 \%$ \\
Ontario & $37.9 \%$ & Conservative on social issues & $23.4 \%$ \\
Quebec & $22.0 \%$ & Liberal on economic issues & \\
West & $32.8 \%$ & Conservative on economic issues & \\
& & & \\
Atheist & $25.6 \%$ & Volunteer/donates to charity & \\
Christan & $54.9 \%$ & & \\
Jewish & $3.0 \%$ & & \\
Muslim & $13.8 \%$ & & \\
Other & $2.7 \%$ & &
\end{tabular}

\section{B. Results}

1. Result 1: The vast majority of respondents support the legalization of payments for plasma donors.

Figure 2 reports the attitudes of the respondents toward legalizing payments for plasma donors. Each column represents the share of participants who expressed support for legal payments in each of the four experimental conditions. The main finding is that the large majority of respondents are in favor of legalizing payments to plasma donors. We estimate that $72.6 \%$ of Canadians are in favor of compensating plasma donors in Canada (95\% c.i. $66.4 \%-78.8 \%$ ), $78.7 \%(95 \%$ c.i. $73.5 \%-84 \%)$ are in favor of compensating plasma donors in 
Australia, and $76.4 \%(95 \%$ c.i. $72.1 \%-80.6 \%)$ are in favor of paying donors in the United States (combining the data from respondents who were given information about the demand and supply of plasma in Canada and those who were given information about Australia). The first-order implication of these results is that a representative sample of Canadians widely supports payments to plasma donors. The differences in support rates for different countries are relatively small and only marginally statistically significant when comparing Canada and Australia (one-tailed t test: $p=0.07$, two-tailed t test: $p=0.14$ ). The stronger support for payments in the U.S. may suggest that respondents display some form of "NIMBY-ism" whereby people enjoy the benefit of a given transaction but do not want to carry the ethical costs of it. The higher support for payments in Australia may suggest some moral relativism, meaning individuals might be more in favor of allowing morally contentious activities if they occur farther away. However, the small differences described above suggest that these mechanisms play only a minor role, if any at all.

2. Figure 2: Support for compensation to plasma donors.

The figure reports the percentage of respondents in each condition who expressed support for legalizing compensation for plasma donors. Error bars represent $95 \%$ confidence intervals $( \pm 1.96 *$ s.e. $)$.

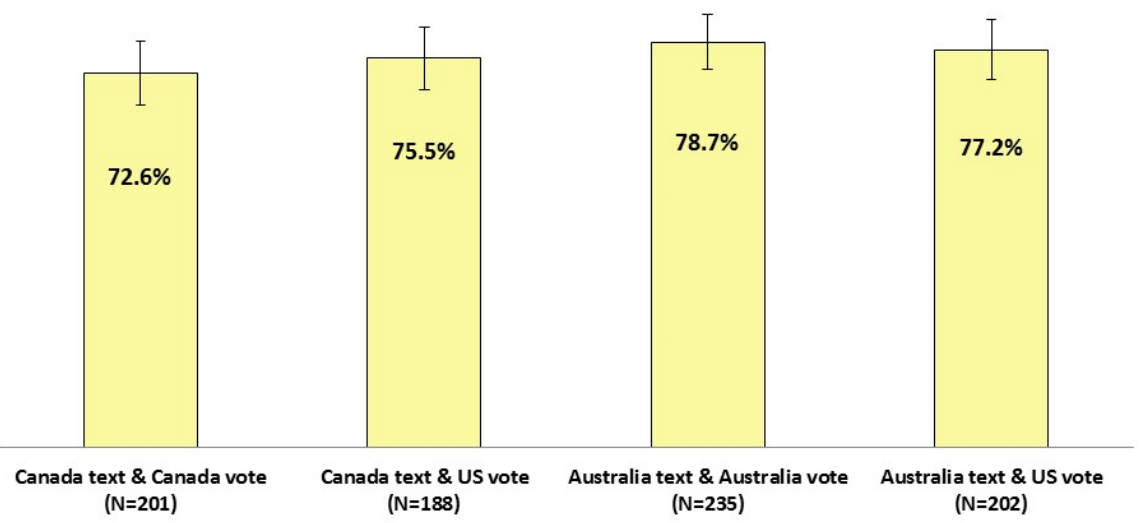

Table 2 reports estimates from Ordinary Least Squares regression models where the outcome variable is a binary indicator for support for plasma donor payments. Estimates in the first column are from a model that included only the indicators for the treatment conditions (as such, these estimates coincide with the statistics reported in Figure 1). The estimates in the second column are from a model that includes controls for the individual characteristics listed in Table 1. Consistent with the random assignment (and the balance of the sample as discussed above), the inclusion of these additional controls did not meaningfully 
change the estimates of the coefficients on the treatment indicators. Moreover, none of the estimates of the parameters on the indicators for the various individual characteristics is statistically significant at the $5 \%$ level or less. This implies that the support rates for compensating plasma donors are very similar across the main socio-demographic categories of the Canadian population.

3. Table 2: Support for payments to plasma donors-regression analysis.

This table reports estimates from Ordinary Least Squares regressions. The dependent variable is equal to one if the respondent expressed support for plasma donor payments and zero otherwise. The main explanatory variables of interest are indicators for the experimental conditions. Column (2) also includes control variables. The omitted treatment indicator (represented by the constant in column (1)) is "Canada text \& Canada vote"; the omitted age category is Age $55+$; the omitted region category is Atlantic; the omitted religion is Jewish. Standard errors are in parentheses $\left(* * \mathrm{p}<0.01,{ }^{*} \mathrm{p}<0.05,+\mathrm{p}<0.1\right)$.

\begin{tabular}{|c|c|c|}
\hline \multirow{2}{*}{$\begin{array}{l}\text { Outcome variable: } \\
\text { Explanatory variables: }\end{array}$} & \multicolumn{2}{|c|}{ Supports payments } \\
\hline & (1) & (2) \\
\hline \multirow[t]{2}{*}{ Canada text \& US vote } & 0.029 & 0.035 \\
\hline & $(0.045)$ & $(0.045)$ \\
\hline \multirow[t]{2}{*}{ Australia text \& Australia vote } & 0.061 & 0.062 \\
\hline & $(0.041)$ & $(0.042)$ \\
\hline \multirow[t]{2}{*}{ Australia text \& US vote } & -0.044 & -0.053 \\
\hline & $(0.060)$ & $(0.061)$ \\
\hline \multirow[t]{2}{*}{ Age $18-34$} & & 0.044 \\
\hline & & $(0.054)$ \\
\hline \multirow[t]{2}{*}{ Age $18-54$} & & -0.017 \\
\hline & & $(0.047)$ \\
\hline \multirow[t]{2}{*}{ Woman } & & -0.051 \\
\hline & & $(0.031)$ \\
\hline \multirow[t]{2}{*}{ East Asian } & & $-0.108+$ \\
\hline & & $(0.065)$ \\
\hline \multirow[t]{2}{*}{ White } & & -0.012 \\
\hline & & $(0.043)$ \\
\hline
\end{tabular}

(continues on next page) 
(continued from previous page)

\begin{tabular}{|c|c|c|}
\hline Ontario & & $\begin{array}{c}-0.041 \\
(0.060)\end{array}$ \\
\hline Quebec & & $\begin{array}{l}-0.057 \\
(0.062)\end{array}$ \\
\hline West & & $\begin{array}{l}-0.010 \\
(0.059)\end{array}$ \\
\hline Married & & $\begin{array}{l}-0.037 \\
(0.036)\end{array}$ \\
\hline With children & & $\begin{array}{c}0.042 \\
(0.036)\end{array}$ \\
\hline Atheist/agnostic & & $\begin{array}{l}-0.069 \\
(0.084)\end{array}$ \\
\hline Christian & & $\begin{array}{c}-0.051 \\
(0.080)\end{array}$ \\
\hline Muslim & & $\begin{array}{r}-0.163+ \\
(0.091)\end{array}$ \\
\hline Other & & $\begin{array}{l}-0.191 \\
(0.126)\end{array}$ \\
\hline College degree & & $\begin{array}{c}0.033 \\
(0.033)\end{array}$ \\
\hline Employed & & $\begin{array}{c}0.015 \\
(0.039)\end{array}$ \\
\hline Retired & & $\begin{array}{l}-0.046 \\
(0.058)\end{array}$ \\
\hline Income $>\$ 50 \mathrm{~K}$ & & $\begin{array}{l}-0.053 \\
(0.036)\end{array}$ \\
\hline Liberal on social issues & & $\begin{array}{c}0.027 \\
(0.043)\end{array}$ \\
\hline Conservative on social issues & & $\begin{array}{l}-0.017 \\
(0.056)\end{array}$ \\
\hline Liberal on economic issues & & $\begin{array}{c}0.002 \\
(0.044)\end{array}$ \\
\hline Conservative on economic issues & & $\begin{array}{c}0.012 \\
(0.050)\end{array}$ \\
\hline Volunteer/donates to charity & & $\begin{array}{c}0.030 \\
(0.035)\end{array}$ \\
\hline Constant & $\begin{array}{l}0.726 * * \\
(0.032)\end{array}$ & $\begin{array}{c}0.855^{* *} \\
(0.130)\end{array}$ \\
\hline Observations & 826 & 824 \\
\hline R-squared & 0.003 & 0.032 \\
\hline Adjusted R-squared & -0.000744 & 0.000817 \\
\hline
\end{tabular}

4. Result 2: Respondents who oppose compensation for plasma donors are mainly concerned about moral issues and the safety of plasma coming from paid donors.

Figure 3 shows cumulative distribution functions of the ratings assigned by respondents who opposed paying plasma donors to the set of motives described in the previous section. For each line, a given point ( $x$ on the horizontal axis, $y$ on 
the vertical axis) indicates the share $y$ of respondents who rated a particular motive $x$ or less. Among respondents who expressed opposition to payments in Australia and Canada, there was a similar distribution of relevance given to morality and safety concerns. The average ratings for the concerns about morality and safety were, respectively, 69.2 and 68.4 for Canada, and 72.6 and 68.9 for Australia. As mentioned above, organizations and authorities that source plasma from countries where donors receive compensation consider the imported plasma to be as safe as the plasma obtained domestically. However, our results indicate a widespread perception among Canadians that paid plasma poses a health threat. At the individual level and especially for those who expressed opposition about paying donors in Canada, there is a strong positive correlation between the concerns for morality and safety (correlation coefficient $=0.54$, significant at the $5 \%$ level). Conversely, the possibility for a country to rely on imported plasma was a much less important reason for the respondents' opposition to allowing payments in that country. The average rating was 35.6 among respondents opposed to paid donors in Canada, and 46.4 among those opposed to paid donors in Australia (two-sided p-value for difference in means $=0.06$; $\mathrm{p}$-value from Kolmogorov-Smirnov test for differences in distributions $=$ 0.053). A possible interpretation of this difference is that Canadians might be reluctant to reveal that they oppose payments to domestic plasma donors because they know that their country can rely on imported plasma from the United States, whereas they might be more likely to reveal this belief when referring to another country. The respondents who were against compensating donors in the United States rated concerns for morality and safety of the collected plasma very similarly to respondents who opposed payments in Canada and Australia. The ratings for these concerns were also similar to the ratings for a third motive that we proposed to these respondents, namely that payments are not needed because the country already runs a supply surplus.

5. Figure 3: Ratings of reasons against compensation.

The graphs below report cumulative distribution functions of the ratings (between 0 and 100) that respondents opposed to legalizing compensation to plasma donors gave to three reasons: "It is immoral to provide monetary payments to plasma donors in Canada/Australia/United States-donations should be unpaid" (labeled "Immoral" in the graphs); "Monetary payments may attract donors who carry transmittable diseases" (labeled "Diseases"); "Increasing the domestic supply of plasma is not a priority, Canada/Australia can rely on imports" (labeled "Can rely on imports"); and, "The US produces more plasma than their domestic needs, so paying plasma donors is unnecessary" (labeled "No need, supply is plentiful"). 


\section{Canada text \& Canada vote}

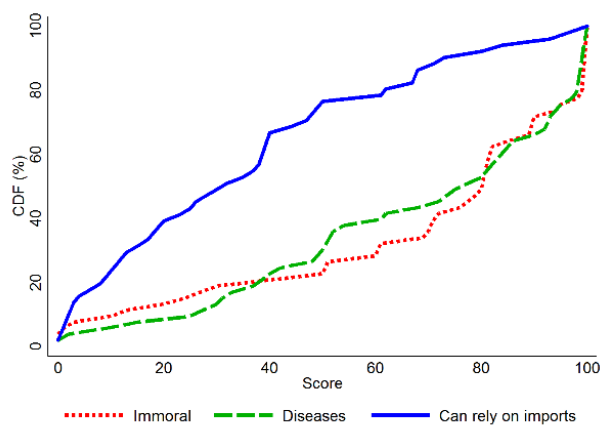

Canada text \& US vote

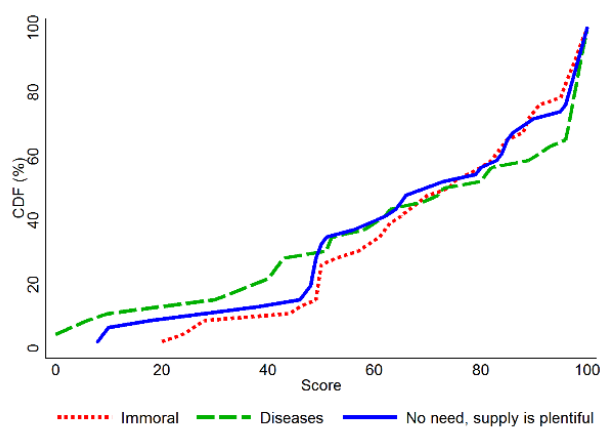

\section{Australia text \& Australia vote}

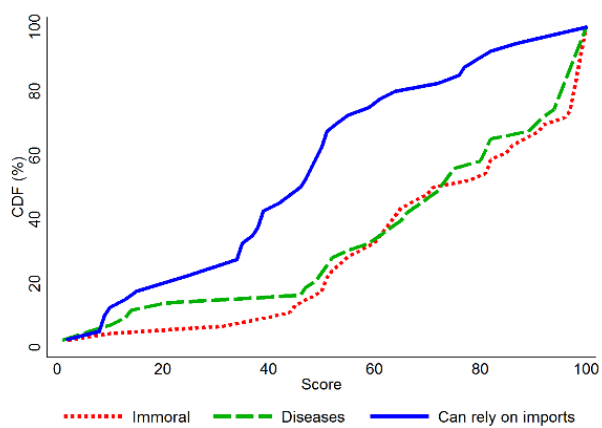

\section{Australia text \& US vote}

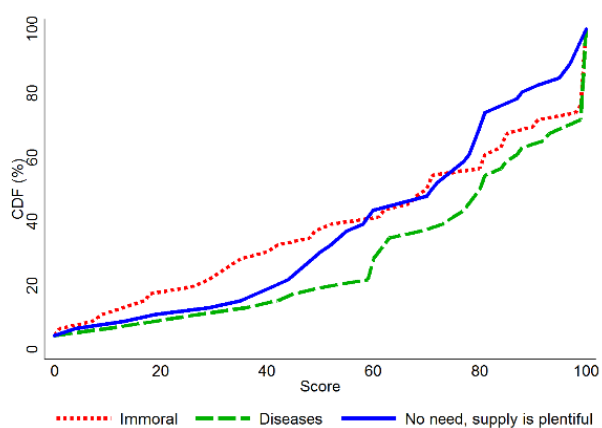

6. Result 3: Respondents who are in favor of payments to plasma donors place great importance on guaranteeing a robust domestic supply of plasma.

Figure 4 presents cumulative distribution functions of the ratings assigned by respondents who favored paying plasma donors to the set of motives described in the previous section. The three motives (labeled "Moral," "Domestic supply," and "Paid elsewhere" in the graphs) all received high ratings and were strongly correlated at the individual respondent level. Securing a higher domestic supply was significantly more important than the other reasons, suggesting that respondents who are in favor of paying plasma donors might be characterized as having more consequentialist (outcome-oriented) views. The respondents who expressed support for the paid-donor system in the United States gave similar ratings to all of the motives they were asked to consider. Again, the importance of guaranteeing a sufficient domestic supply was the reason that received the highest ratings.

7. Figure 4: Rating of reasons for compensation.

The graphs below report cumulative distribution functions of the ratings 
(between 0 and 100) that respondents in favor of compensation to plasma donors gave to the following reasons: "It is morally appropriate to provide monetary payments to plasma donors in Canada (Australia, the United [S]tates) - they incur costs in terms of time spent donating and physical discomfort to supply a valuable resource" (labeled "Moral" in the graphs); "Monetary payments to plasma donors would increase the availability of domestic plasma and reduce Canada's/Australia's dependence on other countries," or, for the United States, "Monetary payments to plasma donors increase the availability of domestic plasma and ensure that the US does not depend on other countries" (labeled "Domestic supply"); "Plasma donors receive monetary payments in some other countries, therefore they should be paid also in Canada/Australia/the United States" (labeled "Paid elsewhere"); "Some countries, such as Canada/Australia, rely on imported plasma from paid donors in the US" (labeled "Other countries rely on US imports"); and, "It is currently legal to pay plasma donors in the US, so things should stay as they are" (labeled "Status quo").

\section{Canada text \& Canada vote}

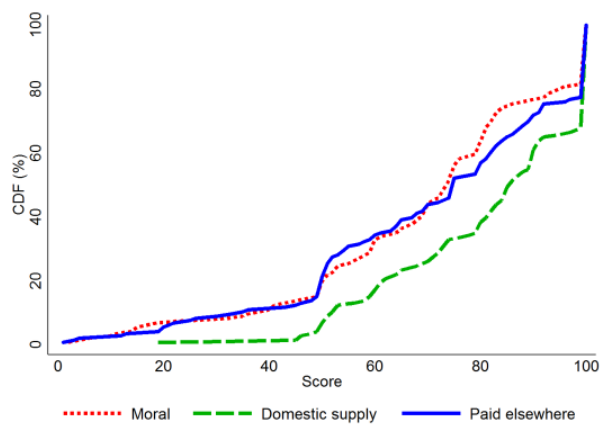

\section{Canada text \& US vote}

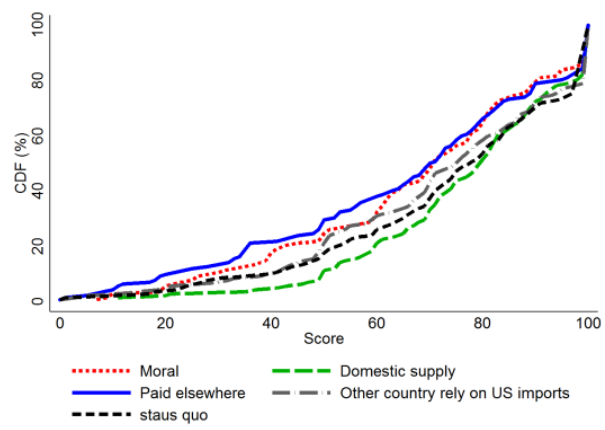

\section{Australia text \& Australia vote}

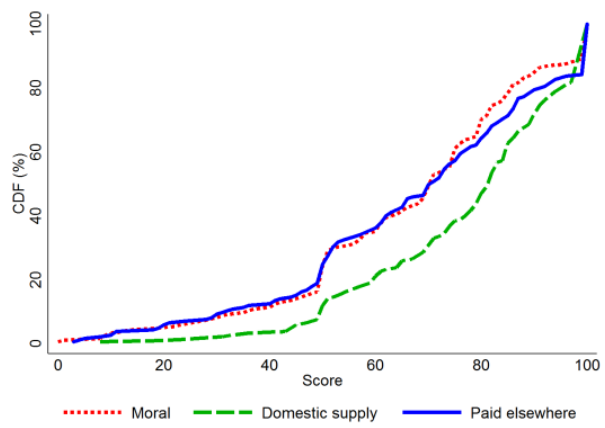

Australia text \& US vote

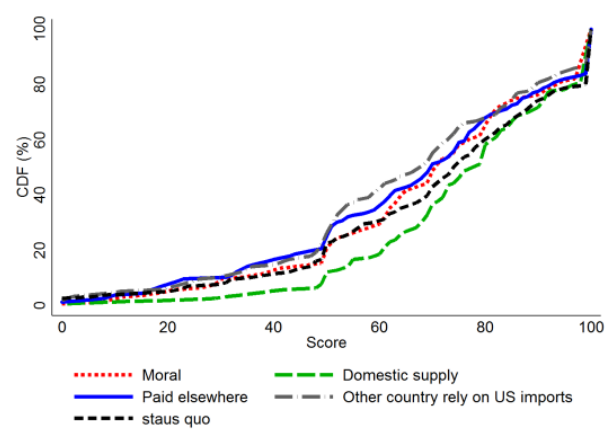


8. Result 4: About half of the respondents who opposed payments would reconsider their position in the case of a supply shortage.

As shown in Figure 5, between 43.5\% (Canada or Australia text \& US vote) and $51 \%$ (Australia text \& Australia vote) of the participants who opposed payments reported that they would be willing to support compensating plasma donors in the case of a supply shortage, that is, if the domestic supply plus imports were insufficient to meet domestic demand. The differences between the treatment groups, however, are not statistically significant both because the differences are not large and because of the relatively small sample sizes of the four groups. These positions were similar across the various socio-demographic characteristics of our respondents, as shown by the regression estimates in Table 3.

9. Figure 5: Percentage of respondents against plasma donor compensation who would reconsider their position in the case of a supply shortage.

The figure reports the shares of respondents who indicated opposition to legal compensation for plasma donors, but who responded that they would consider supporting payments in the case of a supply shortage. Error bars represent $95 \%$ confidence intervals $( \pm 1.96 *$ s.e. $)$.

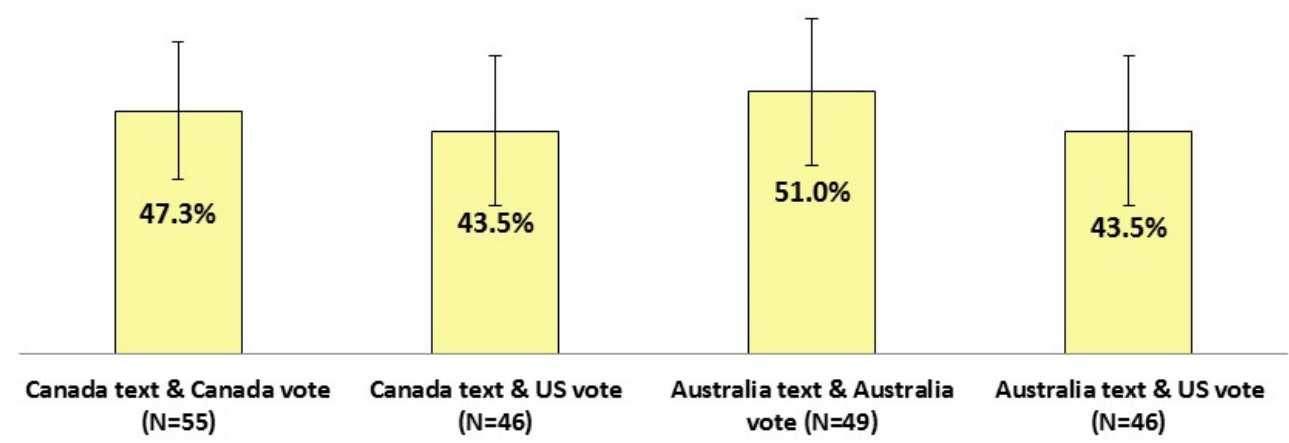

10. Table 3: Support for payments in case of supply shortage-regression analysis.

This table reports the estimates from an Ordinary Least Squares regression. The dependent variable is equal to one if the respondent answered, "Yes I would be in favor of paying plasma donors in case of a supply shortage" - that is, if the domestic supply plus imports were insufficient to meet the domestic needs. The main explanatory variables of 
interest are indicators for the experimental conditions. Column (2) also includes control variables. The omitted treatment indicator (represented by the constant in column (1)) is "Canada text \& Canada vote"; the omitted age category is Age 55+; the omitted region category is Quebec; the omitted religion is Other. Standard errors are in parentheses (** $\left.\mathrm{p}<0.01,{ }^{*} \mathrm{p}<0.05,+\mathrm{p}<0.1\right)$.

Outcome variable: Support if shortage

Explanatory variables:

Canada text \& US vote

$-0.105$

(0.106)

Australia text \& Australia vote

0.024

(0.099)

Australia text \& US vote

0.008

(0.145)

Age 18-34

$0.240+$

(0.125)

Age 18-54

0.078

(0.111)

Woman

$-0.084$

(0.080)

East Asian

$-0.124$

(0.143)

White

$-0.106$

(0.113)

Atlantic

0.183

(0.171)

Ontario

0.005

(0.098)

West

0.099

(0.102)

(continues on next page) 


\begin{tabular}{|c|c|}
\hline \multicolumn{2}{|c|}{ (continues from previous page) } \\
\hline Married & $-0.159+$ \\
\hline & $(0.085)$ \\
\hline \multirow[t]{2}{*}{ With children } & 0.028 \\
\hline & $(0.090)$ \\
\hline \multirow[t]{2}{*}{ Atheist/agnostic } & -0.060 \\
\hline & $(0.215)$ \\
\hline \multirow[t]{2}{*}{ Christian } & -0.121 \\
\hline & $(0.212)$ \\
\hline \multirow[t]{2}{*}{ Jewish } & -0.213 \\
\hline & $(0.329)$ \\
\hline \multirow[t]{2}{*}{ Muslim } & 0.064 \\
\hline & (0.219) \\
\hline \multirow[t]{2}{*}{ College degree } & 0.011 \\
\hline & $(0.081)$ \\
\hline \multirow[t]{2}{*}{ Employed } & -0.082 \\
\hline & (0.099) \\
\hline \multirow[t]{2}{*}{ Retired } & 0.030 \\
\hline & $(0.138)$ \\
\hline \multirow[t]{2}{*}{ Income > \$50K } & -0.024 \\
\hline & $(0.090)$ \\
\hline \multirow[t]{2}{*}{ Liberal on social issues } & 0.053 \\
\hline & $(0.123)$ \\
\hline \multirow[t]{2}{*}{ Conservative on social issues } & $-0.272+$ \\
\hline & $(0.155)$ \\
\hline \multirow[t]{2}{*}{ Liberal on economic issues } & 0.074 \\
\hline & $(0.126)$ \\
\hline \multirow[t]{2}{*}{ Conservative on economic issues } & $0.275+$ \\
\hline & $(0.142)$ \\
\hline \multirow[t]{2}{*}{ Volunteer/donates to charity } & $0.275^{* *}$ \\
\hline & $(0.085)$ \\
\hline \multirow[t]{2}{*}{ Constant } & $0.438+$ \\
\hline & $(0.256)$ \\
\hline Observations & 195 \\
\hline R-squared & 0.175 \\
\hline Adjusted R-squared & 0.0475 \\
\hline
\end{tabular}


As a further attempt to study whether those who were willing to reconsider their opposition to payments held different views and values towards compensation, we compared the ratings they attributed to the various reasons proposed (Figure 6). Overall, and both for respondents who opposed payments in Canada and in Australia, those who would not support compensation, even in case of plasma supply shortage, gave higher importance to moral and safety concerns.

11. Figure 6: Ratings of reasons for being against payments and whether respondents would reconsider their position in case of supply shortage.

The graphs below report cumulative distribution functions of the ratings that respondents who were against compensating plasma donors gave to the three motives the survey asked them to rate (between 0 and 100), separately for those who would support payments in case of supply shortage and those who would still oppose payments even in case of a shortage. "Immoral" stands for the survey statement: "It is immoral to provide monetary payments to plasma donors in Canada/Australia/United States-donations should be unpaid." "Diseases" stands for: "Monetary payments may attract donors who carry transmittable diseases." "Can rely on imports" (only for Canada and Australia) stands for: "Increasing domestic supply of plasma is not a priority, Canada/Australia can rely on imports."

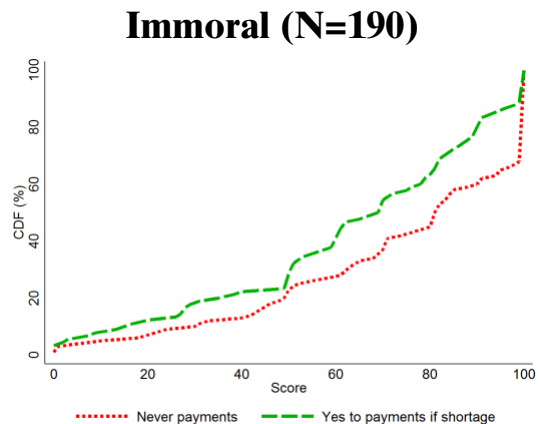

Diseases ( $\mathbf{N}=187)$

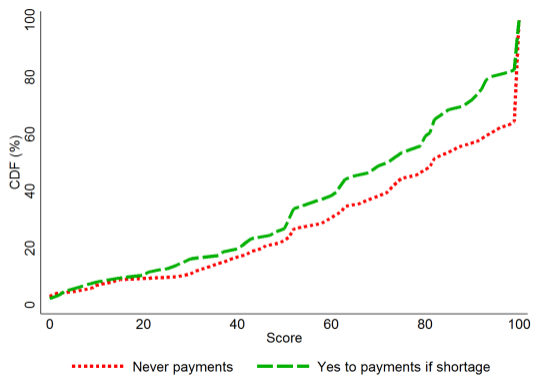

Can rely on imports $(\mathrm{N}=100)$

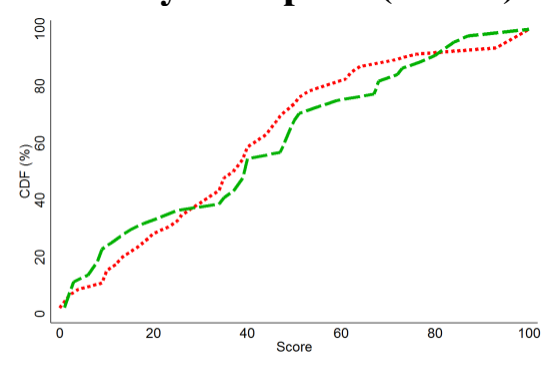

......... Never payments $\quad-0-$ Yes to payments if shortage 


\section{$\mathrm{V}$ \\ CONCLUSION}

The first-order finding from our study is that the vast majority of respondents expressed support for compensation to plasma donors. We found no evidence of widespread societal opposition to payments to plasma donors. Although the support of our Canadian respondents was higher for paying plasma donors in Australia and the United States than in Canada, the differences were small, suggesting a weak role for "moral NIMBY-ism" or moral relativism in explaining the findings. Moreover, there were no differences across the different categories of respondents-for example, by gender, religious attitude, geographical location, age, education, or political orientation. This suggests that attitudes towards payments to plasma donors reflect deep-seated individual traits that observable socio-demographics are unable to predict and that go beyond, for example, gender differences or left-right political preference divides.

Second, moral concerns were the highest-rated reason that respondents gave for being against payments. Respondents also gave high importance to concerns for the safety of plasma supplied by compensated donors, although most of the plasma in Canada does come from compensated American donors. Furthermore, the organizations in charge of the procurement and allocation of plasma have repeatedly assured (and proven) that plasma from American paid donors is as safe as plasma from Canadian unpaid donors. Because safety concerns are unjustified by the evidence, appropriate informational campaigns could help dispel this misconception. More opportunistic considerations, such as the fact that the supply surplus from the United States allows Canada to rely on imports without the need to pay donors domestically, had a much less important role as motivation for opposing compensation.

In contrast, among those in favor of legalizing compensation for donors (in Canada as well as in Australia), the highest-rated motive was to guarantee a higher domestic supply. The majority of the respondents who were in favor of legalizing compensation also agreed that compensation would not run against mainstream Canadian moral and societal values. Most Canadians, therefore, seem to espouse a consequentialist view to issues related to the procurement of plasma.

Because roughly half of those who declared to be against payments reported that they would reconsider their position if the domestic supply and imports were insufficient to meet domestic demand, we may conclude that up to about $85 \%$ of our Canadian respondents share a consequentialist view regarding the regulation of the demand and supply of plasma. Conversely, the remaining approximately $15 \%$ of respondents who continued to oppose payment even when faced with a hypothetical supply shortage can be characterized by deontological preferences: prohibiting payments is a value of a higher order than guaranteeing an adequate supply of plasma. The finding that the attitudes of Canadians toward compensating plasma donors are very similar regardless of whether donors are in 
Canada or elsewhere is consistent with the attitudes reported in the survey and the stated motivations, representing general moral values of the respondents.

In addition to advancing our understanding of individuals' attitudes and social support for morally contentious transactions, our study contributes to the current debate in Canada and elsewhere about whether payments to plasma donors should be legal. The growing demand for plasma, especially for the manufacture of therapeutic products, creates an urgent need for a careful discussion on the relative merits of different procurement and allocation systems in a way that addresses the increasing demand while abiding by the prevailing moral values in a society. We hope that the evidence from this study will provide insights to address these questions of relevance for public health.

More generally, we see our study as supporting a broader philosophy about the role of research in informing societal debates and choices. Many political decisions are thorny because, for example, they involve conflicts between competing societal and moral values and interests that policymakers are called to resolve. Examples include legislation about gestational surrogacy; physicianassisted death; same-sex unions; the donation of organs, blood, plasma and gametes; prostitution; and the treatment of animals in farms, among others. Other political questions, ranging from redistribution policies to the treatment of migrants and refugees, also touch upon rooted beliefs and customs of individuals and societies. In these and similar cases, our view is that a primary role for empirical social scientists is to devise rigorous methodologies to elicit the actual beliefs of the population of interest. Because the choices to be considered often concern activities that are not legal or policies still to be implemented, surveys of individual opinions are often based on hypothetical scenarios and, as such, require some care in interpreting the results. Notwithstanding this caveat, with proper methodological approaches it is possible to provide reliable evidence about the prevailing opinions on complex, morally-charged topics. Of course, in a representative democracy, it is a prerogative of policymakers to not follow the prevailing positions of a population. However, we believe that reliable evidence of these opinions should be, whenever available, considered in the political decision process. 